\title{
CARE BURDEN IN INFORMAL CAREGIVERS OF HEMODIALYSIS PATIENTS: A SYSTEMATIC REVIEW AND META-ANALYSIS STUDY
}

\author{
Azar Jafari Koulaeel, Amir Hossein Goudarzian², Sima beik3, Tahereh Heidari 4, Ali \\ Hesamzadeh 5 \\ 1. MSc Student of Geriatric Nursing, Student Research Committee, Mazandaran University of Medical Sciences, Sari, Iran \\ 2. MSc Student of Psychiatric Nursing, Student Research Committee, Mazandaran University of Medical Sciences, Sari, Iran \\ 3. MSc of Biostatistics, Student Research Committee, Mazandaran University of Medical Sciences, Sari, Iran \\ 4. MSc of Psychiatric Nursing, Student Research Committee, Mazandaran University of Medical Sciences, Sari, Iran \\ 5. Assistant Professor, Ph.D in Nursing, Mazandaran University of Medical Sciences, Sari, Iran
}

Correspondence: alihesam89@yahoo.com

\section{ABSTRACT}

\section{BACKGROUND:}

Correct assessment of care burden in informal care providers to hemodialysis patients such as family members has a crucial role in promoting their physical and mental health. This study was conducted to determine care burden in informal caregivers of hemodialysis patients.

\section{METHODS:}

This systematic review and meta-analysis was performed based on the systematic review meta-analysis and reporting system. To access relevant studies in the field, databases of Medline via PubMed, SCOPUS, ProQuest, SID, Embase and Magiran databases were searched with keywords assigned and using AND \& OR operators until 1st August 2019. After eliminating duplicates and primary and secondary screening of the articles, finally 8 studies entered the meta-analysis process. Cochran test and 12 index were used to determine the heterogeneity of the studies. Random Effects Model was used to estimate pooled mean. Egger's tests were used to evaluate diffusion bias.

\section{RESULTS:}

The level of care burden in informal caregivers of hemodialysis patients varied from 1.7 to 54.01 in 8 studies with a sample size of 651 . Most caregivers were spouses of patients and their mean age ranged from 32 to 51 years. Based on the cumulative graph, the mean total effect for care burden index in caregivers of hemodialysis patients in the studies was estimated to be 8.918 (14.3-454.381) with $95 \%$ confidence interval based on random effect model.

\section{CONCLUSION:}

Considering the care burden in caregivers of hemodialysis patients and its adverse effects, it is recommended to pay more attention to the health of caregivers as hidden patients and appropriate strategies should be considered to improve their quality of life.

KEYWORDS: Care burden, Caregiver, Hemodialysis, Review 


\section{INTRODUCTION}

End-Stage Renal Disease (ESRD) is one of the ten most common causes of public health and one of the ten leading causes of death in the world and people with it need alternative treatments including hemodialysis to survive. [1, 2] Although hemodialysis is one of the main treatment modalities in patients with advanced renal failure, it can be a source of stress for these patients. [3] The need for dialysis and treatment process in these patients leads to significant changes in individual functioning, lifestyle and job loss. [4] Decreased energy levels, repeated need for dialysis and associated health problems affect the ability to perform daily activities and disrupt the usual life of the patient and their caregivers. In fact, due to the chronic nature and long-term treatment of chronic progressive kidney failure, changes in family function are unavoidable.

[5] Various needs in these patients, including medication administration, accompanying the patient for dialysis, the need for lifelong dialysis, daily check-up, maintenance of personal hygiene and appropriate renal diet, as well as frequent hospitalization affect the social, economic and psychological status of caregivers, so that, unfortunately most informal caregivers of hemodialysis patients feel a heavy burden because they have to play an important role in supporting these patients. [6-7]

In one study, the relationship of caregivers to hemodialysis patients was reported as 43.9 percent of their children, 28.10 percent of spouses, 8.8 percent of parents and 19.29 percent others. [8] Care burden includes psychological, physical, and social distress that occurs in caregivers who are most involved in caring of chronic patients. According to the results of some studies, the level of care burden in informal caregivers of hemodialysis patients was mild to moderate. [9] and moderate [10], and in some studies moderate to severe [11] has been reported.

Care burden can have many unpleasant complications in caregivers such as impaired social activity and communication, illness, family relationships disorder, burnout, anxiety, and depression. Therefore, timely identification of these pressures in caregivers has a crucial role in promoting their physical and mental health. [12-13] To date, several descriptive studies have been conducted to assess care burden in caregivers of patients undergoing hemodialysis, with reported levels of caregiver burden varying from mild to severe. [5, 13-16] Given the importance of timely and accurate assessment of caregiver burden and prevention of its adverse effects, it seems that a more comprehensive and accurate study to assess caregiver burden in informal caregivers of patients undergoing hemodialysis is useful. Therefore, the present study was conducted in a systematic review and metaanalysis with the aim to determine the care burden in the caregivers of hemodialysis patients.

\section{METHODS}

This systematic review and meta-analysis were conducted based on the Preferred Reporting Items for Systematic Reviews and Meta-Analyses (PRISMA) in 2019. All steps of the study, such as search, selection of studies, qualitative evaluation and extraction of information were also conducted by two researchers independently. In case of disagreement on the results, the third researcher was used.

\section{SEARCH STRATEGY}

To access relevant studies in the field, databases such as Medline via PubMed, Scopus, Proquest, SID, Embase and Magiran were searched with keywords included "Burden", "Informal Caregiver ", "Hemodialysis" and "Renal Dialysis" by using the Boolean operators (AND \& OR) from 1970 to 1th August, 2019 (Figure 1).

\section{INCLUSION \& EXCLUSION CRITERIA}

Inclusion criteria of studies included: a) keywords listed in the title or abstract of the articles; b) relevant observational studies published in Persian or English. This was after reviewing studies which had conditions such as: a) lack of access to Persian or English full-text, b) incomplete reporting of results and inadequate data.

\section{ARTICLE SELECTION}

In a preliminary search by two researchers, 133 possible articles related to care burden in caregivers of patients undergoing hemodialysis were found. After eliminating duplicates articles, screening by titles, abstract and full text of articles and evaluating the quality of articles, 14 eligible studies entered the systematic review process. Also, 6 studies were excluded due to lack of mean care burden (care burden percentage report) and finally 8 studies were entered in the meta-analysis. Other details are listed in Figure 1. 


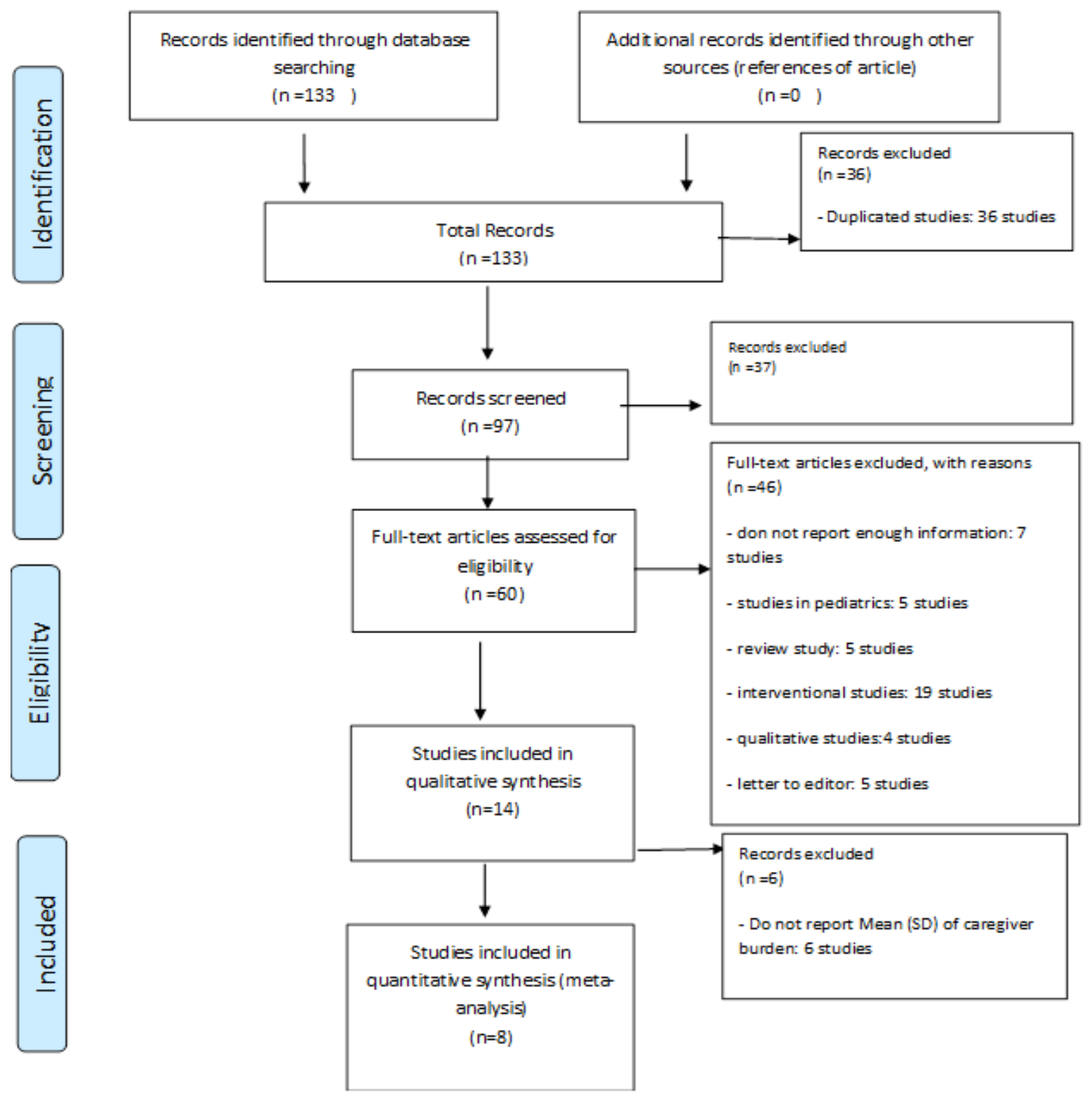

\section{QUALITY ASSESSMENT}

Quality of articles and risk of bias were assessed by using Newcastle-Ottawa scale. Two authors individually computed each article in terms of risk of bias by using the criteria examined that assessed the study design, sampling method, response rate, sample representativeness, objective and reliable determinants of outcome, calculation of study power, and appropriate statistical analysis.

\section{DATA EXTRACTION}

Data from all final articles entered into the study process were extracted by a checklist. The checklist included first author, year of publication, type of study, number and mean age of participants, place of study, caregivers' relationship to patients and level of care burden.

\section{ANALYSIS}

Since the main index in this study was Mean and Standard Deviation, its variance was calculated through normal distribution and $95 \%$ confidence interval. Cochran test and 12 index were used to determine the heterogeneity of the studies. Random Effects Model was used to estimate pooled mean. For estimating pooled estimator (coefficient mean), considering the significance $(P<0.001)$ of index 12 , Random Effects Model was used. Egger's tests were used to evaluate publication bias. According to the test ( $P<0.001$ ), the estimation of homogeneity of the means was rejected, 
so the random effects model was used to analyze the results.

\section{RESULTS}

According to the present review, all studies were performed in Pakistan [9], Iran [5, 8, 11, 12, 21], Turkey [22-
24], Saudi Arabia [25, 7], Japan [26], Oman [27] and Canada. [28] The majority of caregivers were spouses of patients and their mean age ranged from 32 to 51 years. Other details were listed in Table 1.

TABLE 1. CHARACTERISTICS OF INCLUDED STUDIES ( $\mathrm{N}=14)$

\begin{tabular}{|c|c|c|c|c|c|c|c|c|}
\hline $\begin{array}{l}\text { AUTHOR } \\
\text { (YEAR) }\end{array}$ & $\begin{array}{l}\text { STUDY } \\
\text { TYPE }\end{array}$ & COUNTRY & INSTRUMENT & $\begin{array}{l}\text { SAMPLE } \\
\text { SIZE, N (\%) }\end{array}$ & $\begin{array}{l}\text { AGE, } \\
\text { MEAN (SD) }\end{array}$ & $\begin{array}{l}\text { CAREGIVERS' } \\
\text { RELATIONSHIP } \\
\text { TO PATIENTS* }\end{array}$ & $\begin{array}{l}\text { DURATION } \\
\text { OF } \\
\text { CAREGIVI } \\
\text { NG } \\
\text { (YEARS), } \\
\text { MEAN (SD) }\end{array}$ & $\begin{array}{l}\text { CAREGIVER } \\
\text { BURDEN, N } \\
(\%)\end{array}$ \\
\hline $\begin{array}{l}\text { Usman } \\
\text { Shah } \\
\text { (2018) }\end{array}$ & $\begin{array}{l}\text { Cross } \\
\text { sectional } \\
\text { study }\end{array}$ & Pakistan & $\begin{array}{l}\text { Zarit Burden } \\
\text { Interview (ZBI) }\end{array}$ & $\begin{array}{l}\text { Male:97(59) } \\
\text { Female: } \\
67(41)\end{array}$ & $45(11.23)$ & Spouses & $2.2(0.96)$ & $\begin{array}{l}\text { Little or no } \\
\text { burden: } 33(20) \\
\text { Mild to } \\
\text { Moderate:107(65 } \\
\%) \\
\text { Moderate to } \\
\text { Severe:21 (13\%) } \\
\text { Severe :3(2) } \\
\text { Mean(SD)=31.39( } \\
12.31 \text { ) }\end{array}$ \\
\hline $\begin{array}{l}\text { Mashayek } \\
\text { hi (2015) }\end{array}$ & $\begin{array}{l}\text { Descriptive } \\
\text { study }\end{array}$ & Iran & $\begin{array}{l}\text { Caregiver } \\
\text { burden } \\
\text { questionnaire }\end{array}$ & $\begin{array}{l}\text { Male: } 29 \\
\text { (56.1) } \\
\text { Female: } 22 \\
(43.1)\end{array}$ & $42.11(14.78)$ & - & - & $\begin{array}{l}\text { Low: 14(27.5) } \\
\text { Moderate: } 25(49) \\
\text { High: } 12(23.5) \\
\text { Mean (SD) }= \\
54.01(13.41)\end{array}$ \\
\hline $\begin{array}{l}\text { Khiyali } \\
(2018)\end{array}$ & $\begin{array}{l}\text { Descriptive } \\
\text {-analytic } \\
\text { cross- } \\
\text { sectional } \\
\text { study }\end{array}$ & Iran & $\begin{array}{l}\text { Zarit caregiver } \\
\text { burden }\end{array}$ & $\begin{array}{l}\text { Male: } \\
\text { 14(24.57) } \\
\text { Female: } \\
\text { 43(75.43) }\end{array}$ & $48.03(14.23)$ & Children & - & $\begin{array}{l}\text { Mild or no } \\
\text { burden: } 2(3.50) \\
\text { Moderate: } \\
\text { 17(29.80) } \\
\text { Severe: } 38(66.70) \\
\text { Mean (SD) }= \\
49.24(16.19)\end{array}$ \\
\hline $\begin{array}{l}\text { Avsar } \\
\text { (2015) }\end{array}$ & $\begin{array}{l}\text { Cross } \\
\text { sectional } \\
\text { study }\end{array}$ & Turkey & $\begin{array}{l}\text { Zarit } \\
\text { Burden } \\
\text { Interview (ZBI) }\end{array}$ & $68 \mathrm{HD}$ & $\begin{array}{l}\text { Male: } \\
46.0(6.7)\end{array}$ & & $4.0(3.7)$ & $\begin{array}{l}\text { Low: } 31(45.6) \\
\text { Moderate: } \\
\text { 27(39.7) }\end{array}$ \\
\hline
\end{tabular}




\begin{tabular}{|c|c|c|c|c|c|c|c|c|}
\hline & & & & & $\begin{array}{l}\text { Female: } \\
43.1(11.4)\end{array}$ & & & Severe: 10(14.7) \\
\hline $\begin{array}{l}\text { Cantekin } \\
(2016)\end{array}$ & $\begin{array}{l}\text { Descriptive } \\
\text { study }\end{array}$ & Turkey & $\begin{array}{l}\text { Zarit } \\
\text { Caregiver } \\
\text { Burden Scale } \\
\text { (ZCBS) }\end{array}$ & $\begin{array}{l}\text { Female :31 } \\
\text { Male :24 }\end{array}$ & $\begin{array}{l}\text { Female: } \\
38.24(12.3) \\
\text { Male: } \\
4.4(3.08)\end{array}$ & - & $4.4(3.08)$ & $\begin{array}{l}\text { Low: } 7(13) \\
\text { Intermediate: } \\
\text { 23(53.7) } \\
\text { High: 18(33.5) }\end{array}$ \\
\hline $\begin{array}{l}\text { Alnazly } \\
(2015)\end{array}$ & & $\begin{array}{l}\text { Amman and } \\
\text { Irbid }\end{array}$ & $\begin{array}{l}\text { Oberst } \\
\text { Caregiving } \\
\text { Burden Scale } \\
\text { (OCBS) } \\
\text { difficulty } \\
\text { subscale }\end{array}$ & $\begin{array}{l}\text { Male: } 65 \text { (47) } \\
\text { Female: } 74 \\
\text { (53) }\end{array}$ & $32.23(11.78)$ & Son/daughter & $4.93(4.47)$ & Mean $=2.79$ \\
\hline $\begin{array}{l}\text { Alwakeel } \\
(2016)\end{array}$ & $\begin{array}{l}\text { Cross } \\
\text { sectional } \\
\text { study }\end{array}$ & Saudi Arabia & $\begin{array}{l}\text { Caregiver } \\
\text { Burden } \\
\text { Interview (CBI) }\end{array}$ & $\begin{array}{l}\text { Male: } 23(46) \\
\text { Female: } 27 \\
(54)\end{array}$ & $46.6(14.0)$ & Spouse/children & - & $\begin{array}{l}\text { Mean }(S D)= \\
43.3(21.7)\end{array}$ \\
\hline $\begin{array}{l}\text { Washio } \\
\text { (2012) }\end{array}$ & $\begin{array}{l}\text { Cross } \\
\text { sectional } \\
\text { study }\end{array}$ & Japan & $\begin{array}{l}\text { Zarit } \\
\text { careburden } \\
\text { interview (J-ZBI) }\end{array}$ & 108 & $\begin{array}{l}\text { heavily } \\
\text { burdened } \\
\text { caregivers: } \\
64.0(12.0) \\
\text { lightly } \\
\text { burdened } \\
\text { caregivers: } \\
61.7(12.5)\end{array}$ & Spouses & - & $\begin{array}{l}\text { Mean }(S D)= \\
29.3(19.2)\end{array}$ \\
\hline $\begin{array}{l}\text { Bayoumi } \\
\text { (2014) }\end{array}$ & $\begin{array}{l}\text { cross- } \\
\text { sectional }\end{array}$ & Saudi Arabia & $\begin{array}{l}\text { Caregiver } \\
\text { Burden } \\
\text { Interview (CBI) }\end{array}$ & $\begin{array}{l}\text { Male: } 15(30) \\
\text { Female: } 35 \\
\text { (70) }\end{array}$ & $40.6(11.0)$ & Spouse/children & - & $\begin{array}{l}\text { Mean }(S D)= \\
43.3(21.7)\end{array}$ \\
\hline $\begin{array}{l}\text { Rioux } \\
\text { (2012) }\end{array}$ & $\begin{array}{l}\text { Cross- } \\
\text { sectional }\end{array}$ & Canada & $\begin{array}{l}\text { Caregiver } \\
\text { Burden scale }\end{array}$ & $\begin{array}{l}\text { Male: } 11(34) \\
\text { Female: } \\
21(66)\end{array}$ & $51(11)$ & Spouse & - & $\begin{array}{l}\text { Mean }(S D)= \\
1.7(0.5)\end{array}$ \\
\hline Kilic (2017) & Descriptive & Turkey & $\begin{array}{l}\text { Zarit } \\
\text { Caregiver } \\
\text { Burden Scale }\end{array}$ & 210 & - & Spouse & - & $\begin{array}{l}\text { Istanbul: } \\
\text { 31.62(11.38) } \\
\text { Northern Cyprus: } \\
45.77(13.19)\end{array}$ \\
\hline
\end{tabular}

Note: * Most percent

\section{META-ANALYSIS}

The level of care burden in informal caregivers of hemodialysis patients varied from 1.7 to 54.01 in 8 studies with a sample size of 651. also, the lowest care burden was in the study of Rioux et. al in 2012 with an average of 1.7 and the highest care burden was related to the study of Mashayekhi et al. [1 1] In 2015 with an average of 54.01.
Based on the cumulative graph, the mean total effect for care burden index in caregivers of hemodialysis patients was estimated to be 8.918 (95\% confidence interval) and based on randomized effects model was 8.918 (14.4453.381). The heterogeneity index for this study was obtained $\mathrm{I}^{\mathbf{2}}=\mathbf{8 2} / \mathbf{3 \%}$. Other details were listed in Figure 2. 
Sud

D
$\mathrm{E}(96 \% \mathrm{Cl})$

$3139(728,55.55)$

$5401(7.73,8029)$

$4924(17.51,8097)$

$4330(077,8583)$

$2930(8.33,88.93)$

$4330(077,8585)$

$1.70(0.72,208)$

$2.79(0.91,4.87)$

$8.9(3.38,14.48$
$\%$

Weght:

Awakeel (2016)

Washo (2012)

Bajoumi (2014)

Rox 2012

Arazly (2015)

Overal (l-squa $d=82.3 \%, p=0.000)$

NOTE: Weghts are fon random eflects arajgis

1

.$\$ 8$

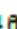

402

284

1.63

200

1.83

4229

4084

100.00

\section{DISCUSSION}

The results of the reviewed studies in this study showed that the level of care burden in most caregivers of patients undergoing hemodialysis was mild to severe, and the levels were varied in different studies. The results showed that informal caregivers of hemodialysis patients in the studies which were conducted in Iran [5, 8, 11, 14, 21] experience more care burden than the caregivers in other studies in other countries (Japan [26], Oman [27], Pakistan [9], Canada [28], Turkey [22-24], Saudi Arabia [25,7]), In fact most of the caregivers in the studies in Iran reported moderate to severe care burden, while in the other countries, the rate was mild to moderate. One of the possible causes of the differences in the results of these studies may be the location of study and cultural diversity among the subjects studied. Also, the role of causes such as the number of hemodialysis sessions per week, insufficient attention given to caregivers by the members of healthcare team to meet their needs, patients' psychological and financial problems and their effects on caregivers' burden is undeniable, which unfortunately, these possible causes have not been reported in these studies to be evaluated in detail. Difference of the tools used to measure care burden in studies may also be one of the possible causes of differences in the results of these studies. 
The results of the meta-analysis also showed that caregivers in the study of Mashayekhi et al. [11] had the highest level of care burden, and caregivers in the study of Rioux et al. [28] suffered the least amount of care burden. The differences in the results of studies can be mentioned that the study of Rioux et al [28] was performed on caregivers of hemodialysis patients at home that it causes hemodialysis to be less interfering with the daily activities of caregivers and caregivers experience less care burden, While in the study by Mashayekhi et al. [11], patients were treated at the hospital with hemodialysis, which makes caregivers more likely to take care of patients and spend more time for caring and transportation of the patient and ultimately, they suffer from more care burden. Other possible reasons for the different results of these two studies $[28,11]$ were the place of study and cultural diversity. The study by Mashayekhi et al. was conducted in Iran [15] and another study performed in Canada. [28] Perhaps the different support resources provided by health care systems for patients and their caregivers and different needs of caregivers have affected the caregiver burden of hemodialysis patients' caregivers. Also, differences in gender for most of the people in two studies could be one of the possible reasons for the differences in the results. Most of the participants in the study of Mashayekhi et al. [15] was male, while the majority of population in the other study were female.

\section{LIMITATION}

One of the limitations of this study is that the search was conducted in only two languages (Persian and English) that could prevent access to all studies in this field, Therefore, more studies are suggested to be conducted on this important issue in future.

\section{CONCLUSION}

Considering care burden in caregivers of hemodialysis patients and its adverse effects, it is recommended that more attention be paid to the health of caregivers as hidden patients when planning by health care team members, and appropriate strategies such as educating the patients and their caregivers, counseling, support resources and referral services to be considered to reduce care burden of caregivers and improve their quality of life. It is also recommended that studies be conducted to investigate effective strategies to reduce the care burden in hemodialysis patients so that by improving the health of caregivers, the quality of care provided to patients and their quality of life can improve. Also, performing systematic Care burden in informal caregivers of hemodialysis patients: a systematic review and meta-analysis study Asia Pacific Journal of Health Management 2020; 15(4):i351. doi: 10.24083/apjhm.v15i4.351 review and meta-analysis studies to properly and timely assess the level of care burden and prevent the unpleasant effects of it can be useful in other diseases such as Alzheimer.

\section{ACKNOWLEDGMENT}

Student Research Committee of the Mazandaran University of Medical Sciences is sincerely appreciated for their financial support of this project. This study was approved by the Student Research Committee of Mazandaran University of Medical Sciences (Grant No: 5969 approved in 2019).

\section{DISCLOSURE}

The authors report no conflicts of interest in this work.

\section{References}

1. Sarmento LR, Fernandes PFCBC, Pontes MX, Correia DBS, Chaves VCB, Carvalho CFA, et al. Prevalence of clinically validated primary causes of end-stage renal disease (ESRD) in a State Capital in Northeastern Brazil. J Bras Nefro. 2018;40(2):130-5.

2. Beizaee Y, Rejeh N, Heravi Karimooi M, Tadrisi SD, Bahrami T. The Effect of Mind-guided Imagery on Decreasing Fatigue in Patients Undergoing Hemodialysis. Iranian Journal of Nursing Research. 2017;12(1):16-22.

3. Pron K, Abdollah Zadeh F, Ghouja Zadeh M, Ahangar $R$. The stressors and adaptability methods for patients undergoing peritoneal dialysis. Nursing \& Midwifery Journal of Tabriz. 2010;5(17):34-41.

4. Rezai R, Hejazi SH, Shahnazarian J, Mahmoudi M, Andi SS. Comparing the body-image in patients undergoing hemodialysis with kidney transplant. Payesh Journal. 2009:8(3):279-87.

5. Talebi M, Mokhtari Lakeh N, Rezasoltani P, Kazemnejad leili E, Shamsizadeh M. Caregiver Burden in Caregivers of Renal Patients under Hemodialysis. Journal of holistic Nursing and Midwifery Sciences. 2016;25(80):59-68.

6. Murtagh FE, Addington-Hall J, Higginson I. The prevalence of symptoms in end-stage renal disease: a systematic review. Advances in chronic kidney disease. 2007;14(1):82-99.

7. Bayoumi M. Subjective Burden on Family Carers of Hemodialysis Patients. Open Journal of Nephrology. 2014; 4:79-85 
8. Khiyali Z, Khani M, Dehghan A. Survey of Caregiver Burden and its related factors in Caregiver of hemodialysis patients referring to Shahid Mohammadi Hospital in Bandar Abbas, 2016. nursing of the vulnerable journal. 2018;5(16):35-46.

9. Usman Shah HB, Atif I, Rashid F, Babar MW, Arshad F, Qamar W, et al. Assessment of caregiver burden of patients receiving dialysis treatment in Rawalpindi. J Pak Med Assoc. 2017;67(10):1498-501.

10. Cagan O, Unsal A, Celik N, Yilmaz AT, Culha I, Eren H. Care Burden of Caregivers of Hemodialysis Patients and Related Factors. International Journal of Caring Sciences. 2018;1 1 (1):279-85.

11. Mashayekhi F, Pilevarzadeh M, Rafati F. The Assessment of Caregiver Burden in Caregivers of Hemodialysis Patients. Mater Sociomed. 2015;27(5): 333-6.

12. Ali Abbasi, Hamid Asayesh, Hossein Rahmani, Alireza Shariati, Seyed Abedin Hosseini, Ghanbar Rouhi, et al. The Burden on Cargivers from Hemodialysis Patients and Related Factors. JGUMS. 2011 ;8(1):26-33.

13. Rahim A, Alhani F, Ahmadi F, Gholyaf M, Akhoond M. Effects of a continuous care model on perceived quality of life of spouses of haemodialysis patients. Eastern Mediterr Health J. 2009;15(4):944-50.

14. Farzi S, Farzi S, Moladoost A, Ehsani M SM, Moieni M. Caring Burden and Quality of Life of Family Caregivers in Patients Undergoing Hemodialysis: A DescriptiveAnalytic Study. IJCBNM. 2019;7(2):88-96.

15. Mashayekhi F, Pilevarzadeh M, Rafati F. The Assessment of Caregiver Burden in Caregivers of Hemodialysis Patients. Mater Sociomed. 2015;27(5):333-6.

16. Sajadi SA, Ebadi A, Moradian S. Quality of Life among Family Caregivers of Patients on Hemodialysis and its Relevant Factors: A Systematic Review. IJCBNM. 2017;5(3):206-18.

17. Panic N, Leoncini E, De Belvis G, Ricciardi W, Boccia S. Evaluation of the endorsement of the preferred reporting items for systematic reviews and metaanalysis (PRISMA) statement on the quality of published systematic review and meta-analyses. Plos one. 2013;8(12): e83138.

18. Ioannidis J. Interpretation of tests of heterogeneity and bias in meta-analysis. J Eval Clin Pract 2008; 14:951-7.
19. Higgins JP, Thompson SG, Deeks JJ, Altman D. Measuring inconsistency in meta-analyses. BMJ Open. 2003;327(7414):557-60.

20. Sterne JA, Harbord R. Funnel plots in meta-analysis. Stata J 2004; 4:127-41.

21. Jafari H, Ebrahimi A, Aghaei A, Khatony A. The relationship between care burden and quality of life in caregivers of hemodialysis patients. BMC nephrology. 2018;19(1):321.

22. Avşar U, Avşar U, Cansever Z, Yucel A, Cankaya E, Certez $\mathrm{H}$, et al., editors. Caregiver burden, anxiety, depression, and sleep quality differences in caregivers of hemodialysis patients compared with renal transplant patients. Transplantation proceedings; 2015: Elsevier.

23. Cantekin I, Kavurmacı M, Tan M. An analysis of caregiver burden of patients with hemodialysis and peritoneal dialysis. Hemodialysis International. 2016;20(1):94-7.

24. Kilic HF, Kaptanogullari H. A Bicommunal Study: Burden of Caregivers of Hemodialysis Patients. International Journal of Caring Sciences. 2017;10(3):1382-90.

25. Al Wakeel JS, Bayoumi MM. Caregiver burden among peritoneal dialysis and hemodialysis family in Saudi Arabia. Kuwait Med J. 2016;48(3):197-201.

26. Washio M, Yoshida $H$, Ura N, Ohnishi H, Togashi N, Sakauchi $F$, et al. Burden among family caregivers of patients on chronic hemodialysis in northern Japan. International Medical Journal. 2012;19(3):221-3.

27. Alnazly EK. Burden and coping strategies among J ordanian caregivers of patients undergoing hemodialysis. Hemodialysis International. 2016;20(1):84-93.

28. Rioux JP, Narayanan R, Chan CT. Caregiver burden among nocturnal home hemodialysis patients. Hemodialysis International. 2012;16(2):214-9. 